\title{
In the name of (de)securitization: Speaking security to protect migrants, refugees and internally displaced persons?
}

\section{Faye Donnelly*}

Faye Donnelly is a Lecturer in the School of International Relations at the University of St Andrews. She is the author of Securitization and the Iraq War: The Rules of Engagement in World Politics (2013). Her article “The Queen's Speech: Desecuritizing the Past, Present and Future of Anglo-Irish Relations" has been published in the European Journal of International Relations, and her work has also appeared in edited volumes and online forums.

\section{Abstract}

This article examines how the protection of migrants, refugees and internally displaced persons (IDPs) is spoken about and framed. Today it is evident that the dominant responses of sovereign States to each of these groups is heavily reliant on the language of security and (de)securitization, and this article openly conceptualizes ongoing attempts to protect migrants, refugees and IDPs as a series of overlapping (de)securitized "games". At least three arguments follow from this claim. First, adopting this approach serves as a reminder that the ways in which different groups of people are spoken about often constitutes a dividing line

* I am grateful to Natasha Saunders for her valuable comments and suggestions. I would also like to thank the anonymous reviewers and editorial team at the International Review of the Red Cross for their help and careful reading of the text. 
between life and death. Second, the language games of (de)securitization are not identical when it comes to protecting different groups. Third, using securitization as the theoretical point of departure provides a timely reminder that none of the three categorizations listed above is guaranteed to apply. On the contrary, the adoption of each linguistic label-migrant, refugee, IDP - is subject to and dependent upon audience acceptance. Remembering the latter dimension is imperative to fully comprehend the ongoing contestations and countermoves in response to people moving in search of security. By way of conclusion, the article contends that far more attention must be paid to broader understandings of acceptance and love to ensure the protection of migrants, refugees and IDPs.

Keywords: securitization, migration, refugees, internally displaced persons, language game, acceptance, love.

Speaking on World Refugee Day in 2016, Barack Obama surmised that " $[\mathrm{t}]$ he scale of this human suffering is almost unimaginable; the need for the world to respond is beyond question". ${ }^{1}$ Unfortunately, this was not an isolated summation. Presenting the highest level of displacement that has ever been on record, in 2016 the Office of the United Nations High Commissioner for Refugees (UNHCR) estimated that "65.3 million people around the world have been forced from home". ${ }^{2}$ A staggering 21.3 million of these people were said to be refugees. Although these dire numbers are alarming, it is necessary to foreground that they are precisely that: numbers, calculations, statistics, figures and estimates.

This is not to suggest that numbers do not matter. For many scholars, they are inherently political and powerful modes of governance. ${ }^{3}$ However, when it comes to calculating the scale and costs of what the then United Nations (UN) Secretary-General, Ban Ki-Moon, termed a "crisis of solidarity" in $2016,{ }^{4}$ it is not enough to simply think or talk in terms of numbers. On the contrary, as the Secretary-General emphasized elsewhere, "we must change the way we talk about refugees and migrants. And we must talk with them. Our words and dialogue

1 The White House, "Statement by the President on World Refugee Day", 20 June 2016, available at: www. whitehouse.gov/the-press-office/2016/06/20/statement-president-world-refugee-day-2016 (all internet references were accessed in August 2017).

2 UNHCR, Global Trends: Forced Displacement in 2015, Geneva, 20 June 2016.

3 See André Broome and Joel Quirk, "The Politics of Numbers: The Normative Agendas of Global Benchmarking", Review of International Studies, Vol. 41, No. 5, 2015; Mark B. Salter, "Imagining Numbers: Risk, Quantification and Aviation Security", Security Dialogue, Vol. 39, No. 2-3, 2008; Judith G. Kelley and Beth A. Simmons, "Politics By Number: Indicators as Social Pressure In International Relations", American Journal of Political Science, Vol. 59, No. 1, 2015; Stephane J. Baele, Thierry Balzacq and Philippe Bourbeau, "It's The Numbers, Stupid! Understanding Quantification in Global Security Governance", European Journal of International Security Blog, 14 June 2017, available at: www. ejis.eu/2017/06/14/its-the-numbers-stupid-understanding-quantification-in-global-security-governance/.

4 Ban Ki-Moon, "Refugee Crisis about Solidarity, Not Just Numbers, Secretary-General Says at Event on Global Displacement Challenge", 15 April 2016, available at: www.un.org/press/en/2016/sgsm17670. doc.htm. 
matter." ${ }^{5}$ In a similar fashion, Pope Francis told members of the US Congress that "we must not be taken aback by their numbers, but rather view them as persons, seeing their faces and listening to their stories, trying to respond as best we can to their situation". 6

With these calls in mind, a guiding concern of this article is to examine how the protection of migrants, refugees and internally displaced persons (IDPs) is being spoken about and framed. Today it is evident that the dominant responses of sovereign States to each of these issues is heavily reliant on the language of security and (de)securitization. ${ }^{7}$ Indeed, this article conceptualizes ongoing attempts to protect migrants, refugees and IDPs as a series of (de)securitized "games". ${ }^{8}$ At least three arguments follow from this claim. First, adopting this lens reminds us that the ways in which we speak about and categorize different groups of people often constitute a dividing line between life and death. Second, the language games of (de)securitization are not identical when it comes to protecting different groups. Third, using securitization as the theoretical point of departure provides a timely reminder that the three discursive labels under consideration are not guaranteed to apply - quite the reverse, in fact. As will be seen below, the adoption of each linguistic label-migrant, refugee, IDP - is subject to and dependent upon audience acceptance. Remembering the latter dimension is imperative to fully comprehend the ongoing contestations over how to respond to people moving in search of security.

The article is divided into six sections. The first section is devoted to exploring how agents are "speaking security" to frame migrants, refugees and IDPs. To get to the crux of these narratives, it may be necessary to move beyond discussions of "security unbound" and catastrophic crises. ${ }^{9}$ The second section outlines the securitization framework created by the Copenhagen School and

5 Ban Ki-Moon, "General Assembly Adopts Declaration for Refugee and Migrants, as United Nations, International Organisation for Migration Sign Key Agreement”, 19 September 2016, available at: www. un.org/press/en/2016/ga11820.doc.htm.

6 Holy See Press Office, "Congress of the United States of America Visit", 24 September 2015, available at: www. usccb.org/about/leadership/holy-see/francis/papal-visit-2015/media-resources/upload/11-EN-congressionaladdress.pdf.

7 References to (de)securitization in the text should be taken to mean securitization and desecuritization.

8 The concept of a "game" has multiple meanings in securitization studies. This article draws directly on Ludwig Wittgenstein's language game approach when it employs this term.

9 Within international relations and critical security studies there is no singular consensus on what "speaking security" means. Given that security is a contested term, there is no single way to speak security. As shown here, some scholars suggest that speaking security pertains to an unbound set of practices, whilst others think that it pertains to catastrophic crises. In this article, the focus on "speaking security" stems in part from the emphasis that the Copenhagen School and its securitization framework place on the role of speech acts in the social construction of security. This grammar is adopted here to explore how agents speak security during ongoing and entangled language games, as well as in wider contexts. The latter point echoes claims made by second-generation securitization scholars, who contend that speaking security is an iterative and interactive practice rather than a single speech act. For two excellent insights into how to conceptualize security as a contested concept, see Matt McDonald and Lee Wilson, "Trouble in Paradise: Contesting Security in Bali", Security Dialogue, Vol. 48, No. 3, 2017; Thierry Balzacq (ed.), Contesting Security: Strategies and Logics, Routledge, London, 2015. 
amended by "second-generation" scholars to demonstrate the power of security speech, moves and practices.

The next three sections are dedicated to exploring how migrants, refugees and IDPs are (de)securitized. The third section questions the promise of using securitization as an analytical lens for mapping varied patterns of migration. Using this discussion as a springboard, the fourth section scrutinizes whether the securitization of migration informs how refugees are labelled, treated and protected. A quick look at countries openly pursing policies that securitize migrants reveals that complications are already establishing themselves in how the two words "migrant" and "refugee" have become synonymous with each other. The fifth section turns the arrow of analysis towards IDPs. The question raised here is whether these groups of persons are silenced by the (de)securitization games unfolding as this piece is being written. The sixth section discusses the prospects of leaving the current games of (de)securitization behind and creating alternative narratives that enable us to see the faces of migrants, refugees and IDPs, to listen to their stories and to respond to their situations.

\section{Unbound securitization and crises? Rethinking security speech, moves and practices}

Established scholars have already illustrated that the language of security plays an extremely powerful role in separating those who are worthy of protection and those who are not, those who are like "us" and those who are not, those who threaten "us" and those who do not, those lives that matter and those that do not. ${ }^{10}$

Yet the language of security can take a variety of forms. Following Ludwig Wittgenstein, the meaning of the word "security" depends on how it is used."11 Evidently, this term can refer to something quite specific (e.g. having enough clothing) or to something more ambiguous (e.g. shadow economies). According to Jef Huysmans, security is "unbound" since it appears to be scattered everywhere, proliferating and rupturing in multiple directions all at once. ${ }^{12}$ Paradoxically, as his work shows, the political effect of this unbinding is the diffusion of insecurities. Concurrently, a wider field of research has highlighted that the language of catastrophic risks, arresting dangers and apocalyptic crises

10 There is a rich body of work on this topic that cannot be captured here or relegated solely to the field of security studies. See Giorgio Agamben, State of Exception, trans. Kevin Attel, University of Chicago Press, Chicago, IL, 2005; Judith Butler, Precarious Lives: The Power of Mourning and Violence, Verso, London, 2006; Judith Butler, Bodies that Matter: On the Discursive Limits of "Sex", Routledge, New York, 1993; David Campbell, Writing Security: United States Foreign Policy and the Politics of Identity, University of Minnesota Press, Minneapolis, MN, 1998; Roxanne Lynn Doty, Imperial Encounters: The Politics of Representation in North-South Relations, University of Minnesota Press, Minneapolis, MN, 1996; Jenny Edkins, Véronique Pin-Fat and Michael J. Shapiro, Sovereign Lives: Power in Global Politics, Routledge, New York, 2004; Lene Hansen, Security As Practice: Discourse Analysis and the Bosnian War, Routledge, London, 2006; Edward W. Said, Orientalism, Penguin, London, 2003.

11 Ludwig Wittgenstein, Philosophical Investigations, trans. G. E. M Anscombe, 3rd ed., Blackwell, Oxford, 1974.

12 Jef Huysmans, Security Unbound: Enacting Democratic Limits, Routledge, London, 2014. 
has become common parlance when it comes to defining what security means and does. ${ }^{13}$ The point of importance here is that references to unbound securities produce a picture of arresting complexity. Arguably, they also create a "void" that actors rush to fill in order to "regulate the meaning of unfolding events". ${ }^{14}$ Yet these attempts seem problematic for two reasons.

First, no complete void ever really exists. Even when they face the most catastrophic crisis - whether it is a "migrant", "refugee" or "IDP" crisis - actors do not inherit a blank slate from which to restart. Hence, there is no bright line separating the discursive practices that exist before a catastrophe and those that are used to make sense of it thereafter. All of a sudden, security is not always unbound, at least not in the sense of any definitive rupture. ${ }^{15}$ Instead, it has to exist within certain limits, irrespective of how ambiguous, porous and blurry these may be. To be clear, this piece is not suggesting that security discourses are somehow predetermined or rigid. If anything, the central argument advanced here illustrates that we are not permanently beholden to pre-existing vocabularies. Nonetheless, what should be avoided is equating the language of crises writ large with an unlimited ability to make security anew each time a catastrophic event appears on the scene. While media headlines throw the spotlight on unbound securities, the meaning of security does not always change at the same momentum, and nor should it. As such, it is necessary to push beyond snapshots that simply show the "newest" or "latest" security crisis. In the process, one can appreciate the intricate ways in which unbound securities and catastrophic crises frequently rely on and even quote what Brent J. Steele terms "critical security narratives". ${ }^{16}$ At the risk of overstating the point, certain residues of meaning continue to matter in ways that are often hard to understand and explain if we only concentrate on the creation of "voids", "catastrophes" and "unbound securities".

It is here that the second fundamental concern surfaces. Crisis after crisis, there tends to be a synergy, a momentum, a rallying call for the implementation of

13 See Louise Amoore and Marieke De Goede, Risk and the War on Terror, Routledge, London, 2008; Claudia Aradau and Rens Van Munster, Politics of Catastrophe: Genealogies of the Unknown, Routledge, London, 2011; Claudia Aradau and Rens Van Munster, "Governing Terrorism Through Risk: Taking Precautions, (Un)Knowing the Future", European Journal of International Relations, Vol. 13, No. 1, 2007; Ulrich Beck, Risk Society: Towards a New Modernity, trans. Mark Rittler, Sage, London, 1992; Didier Bigo, "Security and Immigration: Toward a Critique of the Governmentality of Unease", Alternatives, Vol. 27, Special Issue, 2002; Olf Corry, "Securitisation and 'Riskization': Second-Order Security and the Politics of Climate Change", Millennium: Journal of International Studies, Vol. 40, No. 2, 2012; Dirk Nabers, "Crisis as Dislocation", Politics, Online First View, DOI 10.1177/0263395716661341, 2016.

14 See Jack Holland, "From September 11th, 2001 to 9-11: From Void to Crisis", International Political Sociology, Vol. 3, No. 3, 2009, p. 276; Dirk Nabers, "Filling the Void of Meaning: Identity Construction in U.S. Foreign Policy after September 11, 2011", Foreign Policy Analysis, Vol. 5, No. 2, 2009.

15 For further discussions, see Jef Huysmans and Joao Pontes Nogueira, "Ten Years of IPS: Fracturing IR", International Political Sociology, Vol. 10, No. 4, 2016.

16 Brent J. Steele, "Maintaining (US) Collective Memory: From Hiroshima to a Critical Study of Security History", Critical Studies of Security, Vol. 1, No. 1, 2013; Brent J. Steele, "Critical Security and History", Critical Studies of Security, Vol. 3, No. 3, 2015. According to Steele, critical security history reveals "several functions of historical narratives". He also contends that it is based on the question: "What do dominant narratives of a historical event or process tell us about the subject at hand - the speaker, the community they are in, and beyond?" Ibid., p. 305 (emphasis in original). 
heightened securitized measures. More pointedly, these calls continue to occur even when securitization is already in play. Consequently, one process of securitization appears to breathe life into another. These modes of resuscitation do not have to be identical or complementary; occasionally they will overlap, and at other times they will diverge. Either way, it can be acknowledged that these encounters can be joined together to create larger and intertextual narratives. ${ }^{17}$ To take stock of these landscapes, a number of scholars have turned to concepts like resecuritization ${ }^{18}$ or macrosecuritization. ${ }^{19}$ In different ways, both concepts deal with the intricate ways in which securitization can evolve to organize and bundle "relations around the most powerful call of a given time". ${ }^{20}$ Indeed, Scott D. Watson carves out space for us to study "an intensification of humanitarian securitization". ${ }^{21}$ Going a step further, Amir Lupovici introduces the concept of "securitization climax" to unpack situations in which "actors attempt to justify taking more intensive and

17 James Der Derian and Michael J. Shapiro, International/Intertextual Relations: Postmodern Readings of World Politics, Lexington Books, Lexington, MA, 1989. Lene Hansen's account of one icon quoting another is also very useful in thinking about this point. See Lene Hansen, "How Images Make World Politics: International Icons and the Case of Abu Ghraib", Review of International Studies, Vol. 41, No. 2, 2015, p. 269.

18 Resecuritization does not have a concrete definition in securitization studies. The premise of this concept is that it leaves open a possibility that (de)securitization processes can evolve and change over time. The most common example of resecuritization provided in the literature is an instance where an issue that was desecuritized becomes securitized again. However, arguably, resecuritization can also occur without a securitization process ever ending. In other words, it does not only signal a shift from desecuritization back into securitization. For instance, it is possible that as a securitization process adapts, evolves and intensifies, resecuritization will occur in order to maintain and preserve the game(s) in play. This discussion points to an overlapping potentiality: that institutionalization may constitute a modality of resecuritization. Finally, it is also possible for readers to consider that modes of resistance, contestation and counter-securitization can entail strands of resecuritization. It should be noted that these are only some examples of where one may find resecuritization in operation. For an entry point for further research on this topic, see Matt McDonald, "Deliberation and Resecuritization: Australia, AsylumSeekers and the Normative Limits of the Copenhagen School", Australian Journal of Political Science, Vol. 46, No. 2, 2011; Luca Mavelli, "Security and Secularization in International Relations", European Journal of International Relations, Vol. 18, No. 1, 2011; Fabrizio Tassinari, "The European Sea: Lessons From the Baltic Sea Region for Security and Cooperation in the European Neighbourhood", Journal of Baltic Studies, Vol. 36, No. 4, 2005; Patrick Lebond, "Globalization and World Insecurity", International Studies Review, Vol. 7, No. 4, 2005; Stefano Guzzini, "Foreign Policy Identity Crises and Uses of the 'West'", DIIS Working Paper No.5, 2015.

19 Macrosecuritization relates to the construction of security constellations and securitization processes that bundle and/or hierarchically arrange lower-level securitization processes. See Barry Buzan and Ole Wæver, "Macrosecuritisation and Security Constellations: Reconsidering Scale in Securitization Theory", Review of International Studies, Vol. 35, No. 2, 2009; Barry Buzan, "Will the "Global War on Terrorism' be the New Cold War?", International Affairs, Vol. 82, No. 6, 2006; Juha A. Vuori, "A Timely Prophet? The Doomsday Clock as a Visualization of Securitization Moves with a Global Referent Object", Security Dialogue, Vol. 41, No. 3, 2010; Scott D. Watson, "Macrosecuritization and the Securitization Dilemma in the Canadian Arctic", Critical Studies on Security, Vol. 1, No. 3, 2013; James Sperling and Mark Weber, "NATO and the Ukraine Crisis: Collective Securitization", European Journal of International Security, Vol. 2, No. 1, 2017.

20 B. Buzan and O. Wæver, above note 19, p. 259.

21 Scott D. Watson, "The 'Human' as Referent Object? Humanitarianism as Securitization", Security Dialogue, Vol. 42, No. 1, 2011, p. 9. For another discussion of intensification as a key part of the securitization process, see Michael C. Williams, "The Continuing Evolution of Securitization Theory", in Thierry Balzacq (ed.), Securitization Theory: How Security Problems Emerge and Dissolve, Routledge, London, 2011. 
exceptional measures than those previously accepted by the target audience". ${ }^{22}$ There can be little doubt that these perspectives foster a more holistic understanding of the wider contexts in which security threats emerge and evolve.

However, there are still causes for concern. On the one hand, overarching narratives of this scale may imply that security crises are unending and, by extension, that securitization processes are unbound. They may also ensure that catastrophes become a normal part of our everyday realities. In sync, the exception continues to become the rule. ${ }^{23}$ In some times and places, this picture comes close to reality. Even so, it is worth pondering how productive it is to speak incessantly of catastrophic crises and never-ending threats, and whether the persistent use of these terms makes them difficult to leave behind. ${ }^{24}$ It is easy to imagine the devastating effect of an escalating macrosecuritization that is bundling crisis after crisis together into a compound cluster. The so-called "global war on terror" is an excellent example. To study this enormous metanarrative is to find one securitized agenda breathing life into an elongated chain of other security agendas in ways that were never anticipated, not even by its architects. At present there appears to be no point of saturation, no sign of securitization fatigue or overload. Instead, what can be found is that as more and more security discourses are linked together through this macrosecuritization, it becomes harder to unmake. ${ }^{25}$ This kind of outcome overlaps with Lene Hansen and Helen

22 Amir Lupovici, "Securitization Climax: Putting the Iranian Nuclear Project at the Top of the Israeli Public Agenda (2009-2012)", Foreign Policy Analysis, Vol. 12, No. 3, 2016, p. 413. In another article, Lupovici adopts the term "deep securitization" to ask "what securitization success means in a country with a permanent and deep perception of (traditional) insecurity and in which the state of emergency is already deeply engrained". Amir Lupovici, "The Limits of Securitization Theory: Observational Criticism and the Curious Absence of Israel", International Studies of Review, Vol. 16, No. 3, p. 401. Here, it is important to note that Lupovici draws directly on Uriel Abulof's concept of "deep securitization" to frame his argument. According to Abulof's account, deep securitization occurs when "threats are explicitly framed as probable and protracted, endangering the very existence of the nation/ state and that discourse is incessantly and widely employed by society". Uriel Abulof, "Deep Securitization and Israel's 'Demographic Demon'", International Political Sociology, Vol. 8, No. 4, 2014, p. 397 (emphasis in original).

23 Rens Van Munster, "The War on Terrorism: When the Exception Becomes the Rule", International Journal For the Semiotics of Law, Vol. 17, No. 2, 2004; Claudia Finotelli and Maria Caterina La Barbera, "When the Exception Becomes the Rule: The Spanish Citizenship Regime", Migration Letters, Vol. 10, No. 2, 2013; Mark B. Salter, "When the Exception Becomes the Rule: Borders, Sovereignty and Citizenship", Citizenship Studies, Vol. 10, No. 4, 2008.

24 On this point, see Harmonie Toros, “" $9 / 11$ is Alive and Well' or How Critical Terrorism Studies has Sustained the 9/11 Narrative", Critical Studies on Terrorism, Vol. 10, No. 2, 2017; Barry Buzan, Ole Wæver and Jaap de Wilde, Security: A New Framework for Analysis, Lynne Rienner, London, 1998, pp. 1, 34, 212 .

25 Stephen Graham raises an important insight into how the war on terror has morphed by exploring processes of imitation and appropriation. As a result, his account illustrates that the war on terror has not only evolved from a US perspective over time; in sync, the war on terror has escalated as other actors have strategically learnt how to adapt this language game for use in a different context. Graham's ideas of active learning, shared practices and even overt mimicry are worthy of future research. See Stephen Graham, "Laboratories of War: United States-Israeli Collaboration in Urban War and Securitization", Brown Journal of World Affairs, Vol. 17, No. 1, 2010. For a financial take on the idea of mimicry and the final process of securitization, see David Bassens, Ewald Engelen, Ben Derudder and Frank Witlox, "Securitization Across Borders: Organizational Mimicry in Islamic Finance", Journal of Economic Geography, Vol. 13, No. 1, 2013. 
Nissenbaum's discussion of hypersecuritization in the cyber sector. ${ }^{26}$ As they note, "what distinguishes hypersecuritizations from 'mere' securitization is their instantaneity and inter-locking effects". ${ }^{27}$ Paying attention to these trends raises a flag of concern about moving from one securitized "game" to another without taking a critical step back to explore the configuration or consequences of these larger constellations. Simply put, we must think more about how to leave the language of securitization behind if it continues to grow. This raises more nuanced questions. What happens if securitization becomes unbound? What happens when macrosecuritization becomes hypersecuritized? Can we desecuritize macrosecuritized games and hypersecuritized processes? At which level do we attempt to desecuritize such multi-layered constellations?

With an aim of addressing these questions, this article first conceptualizes securitization and then examines how it shapes discourses on how to protect migrants, refugees and IDPs.

\section{Constructing (de)securitization: The Copenhagen School}

The Copenhagen School and its securitization framework have gained enormous currency in critical security studies. At base, they provide a way to study the social and discursive construction of security. ${ }^{28}$ Inspired by the work of John L. Austin, the Copenhagen School contends that "saying security" does something. More specifically, it argues that speaking security constitutes a securitizing move that frames certain referent object(s) as an existential threat. ${ }^{29}$ This means that security threats are not fixed or objective. Instead they must essentially be understood as discursive articulations of threatened "we" identities. ${ }^{30}$ Although securitizing speech, acts and moves take centre stage in the Copenhagen School's framework, audience acceptance is said to determine whether securitizing moves fail or succeed. ${ }^{31} \mathrm{~A}$ major reason why so much emphasis is placed on audience acceptance collapses back into the Copenhagen School's claim that securitization is an intersubjective and socially constructed process. In equal measure, it supports the Copenhagen School's suggestion that "security should be seen as a negative, as a failure to deal with issues of normal

26 Lene Hansen and Helen Nissenbaum, "Digital Disaster, Cyber Security, and the Copenhagen School", International Studies Quarterly, Vol. 53, No. 4, 2009.

27 Ibid., p. 1164.

28 According to the Copenhagen School, anyone can study and create security. However, the Copenhagen School also suggests that elite actors, such as politicians, will have more authority, power and potential to speak security.

29 B. Buzan, O. Wæver and J. de Wilde, above note 24, pp. 21-25.

30 Ibid., p. 120; also see Jarred Hayes, "Identity and Securitization in the Democratic Peace: The United States and the Divergence of Response to India and Iran's Nuclear Programs", International Studies Quarterly, Vol. 53, No. 4, 2009.

31 B. Buzan, O. Wæver and J. de Wilde, above note 24, p. 25. 
politics". ${ }^{32}$ This possibility might pique curiosity. Does securitization not symbolize a positive outcome?33

In certain circumstances, the Copenhagen School maintains that securitization is "unavoidable". ${ }^{34}$ Within such circumstances, securitization can potentially be viewed as a positive outcome given that with audience acceptance it empowers actors to break free of rules that would otherwise bind them to eliminate the given threat. ${ }^{35}$ However, according to the Copenhagen School, securitization has "problematic side effects". ${ }^{36}$ Precisely because securitization has the power to take issues into the realm of the extraordinary and silence contesting voices, the Copenhagen School maintains that more security is not always better. ${ }^{37}$ Rather, it casts desecuritization as the "optimal long-range option" to move issues "out of this threat-defense sequence and into the ordinary public sphere". ${ }^{38}$ Although the latter concept is contested, Jef Huysmans presents it as an avenue for "unmaking" the fabrication of any security threat that arises in the process of securitization. ${ }^{39}$ According to Thierry Balzacq, Sara Depauw and Sarah Léonard, a general consensus exists within the literature that desecuritization "ought to be sought on the grounds that it would normatively be better than securitization". ${ }^{40}$ In effect, desecuritization signals that securitization was not intended to be unbound.

\section{Reconstructing securitization: Introducing second-generation scholars}

Continued discussions about what securitization is and how it can be applied reinforce the maxim that words gain their meaning in use. ${ }^{41}$ According to "second-generation"

32 Ibid., p. 29.

33 For further insights into the positive and negative effects of securitization, see Rita Floyd, "Can Securitization Theory be Used in Normative Analysis? Towards a Just Securitization Theory", Security Dialogue, Vol. 42, No. 4-5, 2011; Rita Floyd, "Just and Unjust Desecuritization", in T. Balzacq (ed.), above note 9.

34 See B. Buzan, O. Wæver and J. de Wilde, above note 24, p. 29, where they argue that this scenario arises when "states are faced with an implacable or barbarian aggressor".

35 Ibid., pp. 21, 24

36 Ibid., pp. 29, 41.

37 Ibid., pp. 4, 29.

38 Ibid.

39 Jef Huysmans, "The Question of the Limit: Desecuritization and the Aesthetics of Horror in Political Realism", Millennium: Journal of International Studies, Vol. 27, No. 3, 1998, p. 572. Also see Claudia Aradau, "Security and the Democratic Scene: Desecuritization and Emancipation", Journal of International Relations and Development, Vol. 7, No. 4, 2004; Lene Hansen, "Reconstructing Desecuritization: The Normative-Political in the Copenhagen School and Directions on How to Apply It", Review of International Studies, Vol. 38, No. 3, 2012; Philippe Bourbeau and Juha A. Vuori, "Security, Resilience and Desecuritization: Multidirectional Moves and Dynamics", Critical Studies on Security, Vol. 3, No. 3, 2015; Faye Donnelly, "The Queen's Speech: Desecuritizing the Past, Present and Future of Anglo-Irish Relations”, European Journal of International Relations, Vol. 21, No. 4, 2015.

40 Thierry Balzacq, Sara Depauw and Sarah Léonard, "The Political Limits of Desecuritization: Security, Arms Trade, and the EU's Economic Targets", in T. Balzacq (ed.), above note 9, p. 104 (emphasis in original).

41 This is already spelt out by the Copenhagen School, which has noted that "the meaning of a concept lies in its usage": B. Buzan, O. Wæver and J. de Wilde, above note 24, p. 24. 
scholars, securitization is best understood as a continuous process of negotiation, contestation and resistance. ${ }^{42}$ For those orientated towards these more "sociological" approaches, concentrating solely on the semantic side of a security utterance at a single moment in time is too limited. ${ }^{43}$ Instead, they focus on what security speech acts do and, in turn, how the meaning of security can change as securitization unfolds. They also consider what happens when multiple speakers and audiences canvas different and partial viewpoints. In parallel, second-generation scholars have started with the question of silence. ${ }^{44}$ Others still have begun to fold images, ${ }^{45}$ videogames, ${ }^{46}$ emotions, feelings and sensations ${ }^{47}$ into securitization studies.

Taking these broader insights seriously has led many second-generation scholars to conceptualize securitization as a "game". ${ }^{48}$ Encapsulating this stance, Juha A. Vuori describes it as a "type of political game constituted by moves and

42 Second-generation securitization studies represent a huge and still emerging canon of work which cannot be covered here. For excellent overviews of how this debate has unfolded, see Thierry Balzacq, "The Three Faces of Securitization: Political Agency, Audience and Context", European Journal of International Relations, Vol. 11, No. 2, 2005; Thierry Balzacq (ed.), Securitization Theory: How Security Problems Emerge and Dissolve, Routledge, London, 2011; T. Balzacq (ed.), above note 9; Thierry Balzacq, Sarah Léonard and Jan Ruzicka, "Securitization Revisited: Theory and Cases", International Relations, Vol. 30, No. 4, 2016.

43 See the three references by T. Balzacq cited in above note 42; Philipp Klüfers, "Security Repertoires: Towards a Sociopragmatist Framing of Securitization Processes", Critical Studies on Security, Vol. 2, No. 3, 2014; Matt McDonald, "Securitization and the Construction of Security", European Journal of International Relations, Vol. 14, No. 4, 2008; Paul Roe, “Actor, Audience(s) and Emergency Measures: Securitization in the UK's Decision to Invade Iraq", Security Dialogue, Vol. 39. No. 6, 2008; Mark B. Salter, "Securitization and Desecuritization: Dramaturgical Analysis and the Canadian Aviation Transport Security Authority", Journal of International Relations and Development, Vol. 11, No. 4, 2008; Holger Stritzel, "Towards a Theory of Securitization: Copenhagen and Beyond", European Journal of International Relations, Vol. 13, No. 3, 2007; Juha A. Vuori, "Illocutionary Logic and Strands of Securitization: Applying the Theory of Securitization to the Study of Non Democratic Political Orders", European Journal of International Relations, Vol. 14, No. 1, 2008.

44 See Lene Hansen, “The Little Mermaid's Silent Security Dilemma and the Absence of Gender in the Copenhagen School", Millennium: Journal of International Studies, Vol. 29, No. 2, 2000.

45 It has become increasingly common for leading securitization scholars to examine the role of images. For further readings, see Michael C. Williams, "Words, Images, Enemies: Securitization and International Politics", International Studies Quarterly, Vol. 47, No. 4, 2003; Lene Hansen, "Theorizing the Image for Security Studies: Visual Securitization and the Muhammad Cartoon Crisis", European Journal of International Relations, Vol. 17, No. 1, 2011; J. A. Vuori, above note 19.

46 See Mark B. Salter, “The Geographical Imaginations of Video Games: Diplomacy, Civilization, America's Army and Grand Theft Auto IV', Geopolitics, Vol. 16, No. 2, 2011; Felix Ciută, "Call of Duty: Playing Video Games with IR", Millennium: Journal of International Studies, Vol. 44, No. 2, 2016.

47 Emotions and feelings have begun to be studied within securitizations. For interesting insights, see Thierry Balzacq, above note 9; Eric Van Rythoven, "Learning to Feel, Learning to Fear? Emotions, Imaginaries, and Limits in the Politics of Securitization", Security Dialogue, Vol. 46, No. 5, 2015; Ludvig Norman, "Theorizing the Social Foundations of Exceptional Security Politics: Rights, Emotions and Community", Cooperation and Conflict, Vol. 53, No. 1, 2018. To date, sensations are less well studied in security and securitization studies. For an interesting insight on this dimension, see C. Aradau and R. Van Munster, above note 13, pp. 85-106.

48 Faye Donnelly, Securitization and the Iraq War: The Rules of Engagement in World Politics, Routledge, London, 2013; T. Balzacq (ed.), above note 9; Juha A. Vuori, "Contesting and Resisting Security in post-Mao China", in T. Balzacq (ed.), above note 9; Gary T. Marx, "Security and Surveillance Contests: Resistance and Counter-Resistance", in T. Balzacq (ed.), above note 9; Holger Stritzel and Sean C. Chang, "Securitization and Counter-Securitization in Afghanistan", Security Dialogue, Vol. 46, No. 2,2015 . 
countermoves" ${ }^{49}$ A similar suggestion has been put forward by Holger Stritzel and Sean C. Chang to conceptualize countersecuritization: from their point of view, securitization is "as a game of moves and counter-moves in a communicative struggle of adversarial wills". ${ }^{50}$ Envisioning securitization as a game illustrates that the beginning and ending of (de)securitization processes are not clear-cut; instead, such processes can unfold without a fixed script, sound or rhythm. However, there is no uniform definition of what counts as a "game" within securitization studies. ${ }^{51}$ This article draws on the concept of a language game outlined by Ludwig Wittgenstein in The Philosophical Investigations to contribute to debates conceptualizing games of (de)securitization. ${ }^{52}$ This is not to suggest that Wittgenstein's approach is flawless ${ }^{53}$ or that his language game approach is the only way we can conceptualize games in securitization studies. For Wittgenstein, however, the presence of alternative pathways is always welcome as readers continue to "look and see" how security and securitization are spoken, enacted and altered.

\section{Language games and games of (de)securitization}

Studying Wittgenstein's later writings highlights that he considers language games to be an interactive activity. More specifically, he presents language as a "form of life". ${ }^{44}$ Developing this line of argument enables Wittgenstein to show that language is embedded in and constitutive of human actions and interactions. ${ }^{55}$ Put differently, "the term language-game is meant to bring into prominence the fact that the speaking of language is part of an activity, or of a form of life". ${ }^{56}$ Building on these themes, Wittgenstein presents the concept of "meaning in use" 57 to describe how a word, like securitization, becomes meaningful in the process of play. This insight has ramifications for how we understand securitization, since "saying something is an important step, one which must then be constantly put into use to remain in existence" ${ }^{58}$ To talk of "meaning in use" also introduces multiplicity and overlaps since any word can acquire a different set of meanings in the course of play. Moreover, the meanings in one language game can come to criss-cross with another language game, which, in turn, can also come to criss-cross with another, and so forth. In short, meanings are

49 J. A. Vuori, above note 48, p. 191.

50 Holger Stritzel and Sean C. Chang, "Securitization and Counter-Securitization in Afghanistan", Security Dialogue, Vol. 46, No. 6, 2015.

51 For most second-generation scholars, the concept of a game does not have a single definition. To date, it has tended to be tied to their idea of ongoing "practices" of contestation.

52 L. Wittgenstein, above note 11.

53 Arguably a language game approach is haunted by the priority it places on language rather than more visual and material dimensions of speech. However, a closer reading of Wittgenstein's approach demonstrates that it allows for interrelations between these aspects.

54 Ibid., $\$ 23$, p. 11 .

55 A daily exchange of greetings would be an example of how language is a form of life.

56 Ibid., $\$ 23$, p. 11

57 Ibid., $\$ 43$, p. 20.

58 F. Donnelly, above note 48, p. 76. 
layered. To capture these pluralistic dimensions, Wittgenstein adopts the term "family resemblances". 59 This idea explains how security can refer to shadow economies and having enough clothes simultaneously. It is crucial to note that Wittgenstein's rationale does not only allow for a single word to have multifarious meaning; it also allows for players to undertake multiple moves within a single game on the one hand, whilst participating in more than one game on the other. Adding another layer of analysis, Véronique Pin-Fat notes that "the people with whom we are in relation may also be in motion, moved to change themselves". 60

Taking a cue from Wittgenstein, then, the limits of any language game are never secure since the flow of the game can always be changed. Nevertheless, they are never totally unbound. Conversely, within every single language game, agents draw on rules "as a matter of course". ${ }^{61}$ The idea of rules being obeyed, followed and used does not mean they cannot be disobeyed, broken or thrown away. Nevertheless, Wittgenstein maintains that rules are always present since we cannot "know how to go on" without them. ${ }^{62}$ This represents another important change in how we conceptualize securitization. ${ }^{63}$ Whilst securitized games are presented as a set of practices that empower players to break free of rules that would normally hold, Wittgenstein maintains that there will always be some kind of rules in operation, even when security is spoken and securitizing moves are accepted. At the very least, "departing from one set of rules or interpreting them differently requires some form of justification". ${ }^{64}$ Meanwhile, actions that plainly break the rules of one game without any justification can be penalized.

Whether taken individually or collectively, Wittgenstein's insights help us to appreciate how the protection of migrants, refugees and IDPs can come to gain multiple meanings in certain language games. What he also helps us realize is that rules are in jeopardy if we allow actors to break them without any consequences. ${ }^{65}$ Worse still, words and rules can become meaningless if we repeatedly fail to put them into use.

59 L. Wittgenstein, above note $11, \$ 67$, p. 32.

60 Véronique Pin-Fat, "Writing Narrative as Ethics and Philosophy in International Relations: Reflections on a Difficulty in Writing a Research Monograph", Journal of Narrative Politics, Vol. 3, No. 1, 2016.

61 L. Wittgenstein, above note $11, \$ 238$, p. 87 (emphasis in original).

62 Ibid., $\$ 179$, p. 73.

63 For further discussion on the role of rules in securitization, see, B. Buzan, O. Wæver and J. de Wilde, above note 24, pp. 25-26; F. Donnelly, above note 48, pp. 56-60; Michael C. Williams, above note 21, pp. 217218; Jonathan Bright, "Securitization, Terror and Control: Towards a Theory of the Breaking Point", Review of International Studies, Vol. 38, No. 4, 2012.

64 F. Donnelly, above note 48, p. 83.

65 Drawing on Wittgenstein's writings, it is possible to conceptualize international law and codified conventions established to protect migrants, refugees and IDPs as language games that abide by specific sets of rules. For further reading on this connection, see Wouter Werner, "What is Going On? Reflections on Kratochwil's Concept of Law", Millennium: Journal of International Studies, Vol. 44, No. 2, 2016; Friedrich Kratochwil, The Status of Law in World Society: Mediations on the Role of Rule and Law, Cambridge University Press, Cambridge, 2014; Norman Malcolm, "Wittgenstein on Language and Rules”, Philosophy, Vol. 64, No. 247, 1989. 


\section{The securitization of migration: A fait accompli?}

This section taps into debates surrounding the securitization of migration in order to problematize storylines that depict this process as a fait accompli. The logic that migrants pose a threat to national security is now a prominent technique employed by States to manage their territorial borders. As Philippe Bourbeau notes, "the movement of people is provoking worldwide anxiety and apprehension and casting long-established questions of cultural identity, belonging, and security into a state of uncertainty". ${ }^{66}$ Similar views have been articulated by key political figures in the United Kingdom. As then home secretary Theresa May quipped, large-scale migration made a "cohesive society" impossible. ${ }^{67}$ Adopting a more securitizing tone towards migrants and refugees living in makeshift camps in Calais, David Cameron, then prime minister, maintained that there is "a swarm of people coming across the Mediterranean, seeking a better life, wanting to come to Britain because Britain has got jobs, it's got a growing economy". ${ }^{68}$ The campaign slogans championed by political parties backing "Brexit" have escalated matters. ${ }^{69}$ As Nigel Farage's UK Independence Party anti-immigration poster maintained, the nation was at "breaking point" and "the EU had failed". ${ }^{70}$

Yet there is nothing in the broadest arc of these tales that deviates from the securitization of migration taking place in other countries. Among "Western" societies alone, a long list of comparisons can be drawn, ranging from the United States to Australia to Greece. ${ }^{71}$ Hence, as Scott D. Watson points out, "the association of human migration with insecurity is not new".72 Against this backdrop, signs are emerging to suggest that the securitization of migration is now a fait accompli.

Adopting a language game perspective, however, it is worth remembering that this type of account is misleading for several reasons. First, nothing is ever a

66 Philippe Bourbeau, The Securitization of Migration: A Study of Movement and Order, Routledge, London, 2011.

67 “Theresa May Pledges Asylum Reform and Immigrant Crackdown”, BBC News, 6 October 2015, available at: www.bbc.co.uk/news/uk-politics-34450887.

68 Jessica Elgot and Matthew Taylor, "Calais Crisis: Cameron Condemned for 'Dehumanising' Description of Migrants", The Guardian, 30 July 2015, available at: www.theguardian.com/uk-news/2015/jul/30/ david-cameron-migrant-swarm-language-condemned.

69 Faye Donnelly and Jasmine K. Gani, "The \#LondonIsOpen Campaign: Desecuritizing Brexit?", E-International Relations, 21 June 2017, available at: www.e-ir.info/2017/06/21/the-londonisopencampaign-desecuritizing-brexit/.

70 Heather Stuart and Rowena Mason, "Nigel Farage's Anti-Immigrant Poster Reported to Police", The Guardian, 16 June 2016, available at: www.theguardian.com/politics/2016/jun/16/nigel-farage-defendsukip-breaking-point-poster-queue-of-migrants.

71 For further discussions on the securitization of migration, see Alessandra Buonfino, "Between Unity and Plurality: The Politicization of Migration", New Political Science, Vol. 26, No. 1, 2004; Ayse Ceyhan and Anastassia Tsoukala, "The Securitization of Migration in Western Societies: Ambivalent Discourses and Societies", Alternatives, Vol. 27, Special Issue, 2002; Georgios Karyotis, "Securitization of Migration in Greece: Process, Motives and Implications", International Political Sociology, Vol. 6, No. 4, 2012; Georgios Karyotis and Stratos Patrikios, "Religion, Securitization and Anti-Immigration Attitudes: The Case of Greece", Journal of Peace Research, Vol. 47, No. 1, 2010.

72 Scott D. Watson, The Securitization of Humanitarian Migration: Digging Moats and Sinking Boats, Routledge, London, p. 15. 
fait accompli since words can change meaning, for better or worse, in the course of play. Second, paying attention to Wittgenstein's concept of multiplicity shows that migration is not a crisis for all migrants. In short, not all migrants are being labelled as a security threat. Instead, the securitization of migration creates multi-layered processes of identification and discrimination between those deemed to have entered through the "regular" channels and those who have entered through "illegal" or "irregular" ones. ${ }^{73}$ The presence of this discursive layering and labelling challenges claims that the securitization of migration is a fait accompli. Third, oversimplifying the securitization of migration blinds us to who migrants are. Framing migrants as a security threat creates and reproduces negative stereotypes of external groups. On closer inspection, these modes of identification fray in reality. Indeed, William Lacy Swing, general director of the International Organization for Migration, has calculated that "one in every seven of us is a migrant" ${ }^{74}$ Despite this statistic, however, diverse groups of migrants are being homogenized, helping to maintain a singular and anonymized "other". Fourth, omnipotent securitized narratives about migrants are making it difficult for alternative narratives to be heard. Certainly across Europe, perceptions of migration have changed significantly, as country after country has moved to close or restrict its borders. As a result, hateful speech about migrants has undoubtedly risen, as have violent actions against them. ${ }^{75} \mathrm{~A}$ report produced by the Danish Institute of International Security also maintains that the assumptions that "refugees are vulnerable to radicalization" and that refugee flows provide "a backdoor for terrorists" are gaining political momentum. ${ }^{76}$ As will be shown below, these speech acts, moves and practices jeopardize the protection of many refugees trying to escape violence. Finally, the securitization of migration prompts one to wonder how to leave securitized games behind. This matters given that ongoing attempts to desecuritize migration are under duress. ${ }^{77}$

73 Fiona H. McKay, Samantha L. Thomas and Susan Kneebone, “"It Would Be Okay if They Came through the Proper Channels': Community Perceptions and Attitudes toward Asylum Seekers in Australia”, Journal of Refugee Studies, Vol. 25, No. 1, 2011.

74 William Lacy Swing, "Statement of IOM Director General William Lacy Swing at the September Summit and Signing of the IOM-UN Agreement", 19 September 2016, available at: www.iom.int/speeches-andtalks/statement-iom-director-general-william-lacy-swing-september-summit-and-signing.

75 Since the Brexit vote, a spike in the number of hate crimes has been reported and recorded. See " Record Hate Crimes' After EU referendum”, BBC News, 15 February, 2017, available at: www.bbc.co.uk/news/uk38976087.

76 Manni Crone and Maja Felicia Falkentoft, Europe's Refugee Crisis and the Threat of Terrorism: An Extraordinary Threat?, Danish Institute for International Studies, Copenhagen, 2017, available at: pure. diis.dk/ws/files/910914/Report_05_Europes_Refugee_Crisis_Web.pdf.

77 See Vicki Squire, Angeliki Dimitriadi, Nina Perkowski, Maria Pisani, Dallal Stevens and Nick VaughanWilliams, Crossing The Mediterranean Sea by Boat: Mapping and Documenting Migratory Journeys and Experiences, Final Report, 4 May 2017, available at: www2.warwick.ac.uk/fac/soc/pais/research/ researchcentres/irs/crossingthemed/ctm_final_report_4may2017.pdf. 


\section{The securitization of refugees: A contradiction in terms?}

In theory, the securitization of migration should have absolutely no bearing on the protection of refugees. Labelling someone as a refugee should ensure that they are not framed as an existential threat. To borrow from the poem "Home" by Warsan Shire, "You have to understand that no one puts children in a boat unless the water is safer than the land." 78 Abiding by various iterations of international refugee law, when a person is awarded refugee status, it should automatically entitle them to rights and protections. It should also automatically endow the international community with responsibilities to watch over them. These principles are why UNHCR was created in 1950 and why the Refugee Convention ${ }^{79}$ was approved by the UN in $1951 .{ }^{80}$

These simple creeds are not always reflected in practice, however. ${ }^{81}$ One reason for this stems from the escalation of securitized games in operation to manage internal and external migration flows. The deal struck between the European Union and Turkey on 18 March 2016 is a case in point. ${ }^{82}$ Here, one securitized game is breathing life into another. Apart from simply framing migrants as threats, this deal represents a toxic form of discursive osmosis that has attempted to recast both refugees and asylum-seekers as threats rather than persons who are threatened. ${ }^{83}$ Although the words "migrant" and "refugee" are now held to share family resemblances, they do not abide by the same sets of rules.

Take, for example, the international law principle of non-refoulement, ${ }^{84}$ which categorically prohibits States from returning refugees and asylum-seekers to any territory where their security will be jeopardized and where they have

78 This poem resonated with many audiences around the world. It was widely (re)tweeted and used as part of a charity single/song to raise awareness about the refugee crisis. For access to the entire poem and information about how it was circulated, see Martha Bausells and Maeve Shearlaw, "Poets Speak Out for Refugees: 'No One Leaves Home, Unless Home is the Mouth of a Shark'", The Guardian, 16 September 2015, available at: www.theguardian.com/books/2015/sep/16/poets-speak-out-for-refugees-.

79 Convention relating to the Status of Refugees, 189 UNTS 137, 28 July 1951 (entered into force 22 April 1954).

80 See Natasha Saunders, "Paradigm Shift or Business as Usual? An Historical Appraisal of the 'Shift' to the Securitization of Refugees", Refugee Studies Quarterly, Vol. 33, No. 3, 2014; Natasha Saunders, International Political Theory and the Refugee Problem, Routledge, New York, 2018.

81 See Young Hoon Song, "International Humanitarian Response and Militarization of Refugee and IDP Camps in Kenya and Sudan", Journal of International and Area Studies, Vol. 19, No. 1, 2012.

82 See Elizabeth Collett, "The Paradox of the EU-Turkey Refugee Deal”, Migration Policy Institute, March 2016, available at: www.migrationpolicy.org/news/paradox-eu-turkey-refugee-deal.

83 See Alexandria J. Innes, "When the Threatened Become the Threat: The Construction of Asylum Seekers in British Media Narratives", International Relations, Vol. 24, No. 4, 2010; Saskia Llewllyn, "Testing the Solid in Solidarity: An Examination of Why the Ongoing Refugee Crisis is the Most Important Challenge Facing the EU", Quarterly Access - Australian Institute of International Affairs, Vol. 9, No. 3, 2016.

84 As Cordula Droege, amongst others, notes, the principle of non-refoulement is codified in refugee law, extradition treaties, international humanitarian law and international human rights law. Within these legal frameworks there is also some variation regarding the persons whom this principle protects. For further discussion, see Cordula Droege, "Transfers of Detainees: Legal Framework, Non-Refoulement and Contemporary Challenges", International Review of the Red Cross, Vol. 90, No, 871, 2008; Jean Allain, "The Jus Cogens Nature of Non-Refoulement", International Journal of Refugee Law, Vol. 13, No. 4, 2002; Aoife Duffy, "Expulsion to Face Torture? Non-Refoulement in International Law", International Journal of Refugee Law, Vol. 20, No. 3, 2008. 
reason to fear persecution. This principle stands in sharp contrast to ongoing attempts to deny asylum claims before they are fully processed ${ }^{85}$ It also prohibits moves undertaken to send refugees and asylum-seekers home or to detainment centres whilst they are in transit. In effect, the creation of such securitized agendas signals a contradiction in terms and a growing redundancy for the legal apparatus that is meant to protect refugees and asylum-seekers. Looking ahead, these trends are alarming since they may also signal the construction of a new set of rules for determining who "counts" as a refugee and what protections they should be afforded.

There is one scenario where securitization could be linked to protecting refugees and asylum-seekers. It is one in which refugees are allowed to be the speakers, and the international community to be the audience. ${ }^{86}$ In this case, the game shifts gears. Technically, it would allow refugees and asylum-seekers to speak security in order to frame the State from which they are fleeing as an existential threat. Under international law, the power of these speech acts stems from their ability to allow refugees and asylum-seekers to break free of rules that would otherwise bind, like crossing a national border without a passport, a residence permit, a piece of jewellery or a penny to their name. This, however, is where the workings of unbound securitization games and crises resurface. A distressing lesson to learn from the so-called "refugee crisis" 87 is that audiences 88 require more convincing than they should when it comes to accepting speech acts and securitizing moves undertaken by refugees and asylum-seekers. For example, as the "refugee crisis" has escalated, audiences want further clarifications. As a result, refugees are asked with increased frequency to prove that "their" claims

85 As the migration and refugee crises in Europe have escalated, for example, the European Union (EU) has introduced several bureaucratic procedures and tougher rules to manage the flow of people into this territory. In July 2016, this organization openly stated that "asylum seekers moving to other EU countries after arriving in Europe will face having their applications for international protection rejected". For further information on the EU procedures, see James Crisp, "Refugees Face Asylum Rejection if they Leave Country of Arrival, Under New EU Rules", Euractiv, 13 July, 2016, available at: www.euractiv.com/section/global-europe/news/under-new-eu-rules-refugees-face-asylum-rejectionif-they-leave-country-of-arrival/; Natascha Zaun, EU Asylum Policies: The Power of Strong Regulating States, Palgrave Macmillan, Cham, 2017. The author is grateful to Natasha Saunders for her advice to put stronger emphasis on this point.

86 Obviously it is also possible that the international community and humanitarian organizations like UNHCR securitize refugees as a way to safeguard their right of survival. Here again their securitizing moves are dependent on audience acceptance from host States. On this point, see Jocelyn Vaughn, "The Unlikely Securitizer: Humanitarian Organizations and the Securitization of Indistinctiveness", Security Dialogue, Vol. 40, No. 3, 2009. Also see Anne Hammerstad, "UNHCR and the Securitization of Forced Migration", in Alexander Betts and Gil Loescher (eds), Refugees in International Relations, Oxford University Press, Oxford, 2011.

87 The term "so-called" is deliberately used here to draw attention to the active construction of this discursive label and to problematize the naturalization of coining these refugee flows as a "crisis".

88 The fact that there is not a singular audience listening to these claims adds another layer of complexity that has hampered many claims for asylum. Technically, the international community writ large is one audience that refugees speak to when they make their claims for protection and humanitarian assistance. Host governments and their populations are two other audiences listening to and processing their asylum claims. For analytical purposes, however, the author prefers to retain some degree of anonymity when discussing the audiences since there are often many audiences in play that do not neatly fall into official categories. 
for asylum are legitimate, to verify that "they" are not a migrant or terrorist, to provide evidence that "they" came through the correct channels, to confirm how long "they" wish to stay. This is not the end of the process, since audiences weighing up the legitimacy of these speech acts and securitizing moves then proceed to check whether "they" will overtax their refugee quota and calculate how much it will cost to resettle "them" and "their" families.

Needless to say, these scenarios are hypothetical by design. In turn, some may dismiss them as an unfair demonization of the audience that is supposedly engaging with refugees in this fashion. Others may take this author to task for trivializing important dimensions of refugee settlement programmes and legitimate asylum procedures. On both counts, perhaps an apology should be issued. Even so, the bigger question that should not fall through the cracks is how it has become possible for refugees and asylum-seekers to be framed as anything other than people who are existentially threatened.

\section{The securitization of IDPs: A missing category of concern?}

So far, the "migration" and "refugee" crises occurring across the world have been discussed. The purpose of this section is to illustrate that "for all those that flee, others stay behind, some choosing to take up weapons, others believing they can 'ride out the storm'" 89

While IDPs are not gaining much coverage within the securitized games surrounding the "migrant" and "refugee" crises, they are threatened. Concerns about food, shelter, health, belonging and living are ritualistically interwoven into their everyday existence. Compounding these concerns is the fact that the internally displaced remain in a hostile domestic environment where they can become more vulnerable to forcible resettlement, sexual assault and food deprivation. ${ }^{90}$ As Monika Barthwal-Datta indicates, "without financial means to leave the country, IDPs are dependent on the local or national authorities for assistance, even for basic survival". ${ }^{91}$ It is also well established that IDP camps are fertile ground for militarization, ${ }^{92}$ with encampment policies leading to active recruitment of rebel groups and child soldiers. ${ }^{93}$ Within IDP camps, militarization can also happen through the siphoning of humanitarian funding and other resources for small arms sales. As a result, "the distinction between

89 Will H. Moore and Stephen M. Shellman, "Refugee or Internally Displaced Person? To Where Should One Flee?", Comparative Political Studies, Vol. 39, No. 5, 2006, p. 599; Jon Bennett, "Forced Migration Within National Borders: The IDP Agenda", Forced Migration Review, Vol. 1, April 1998.

90 Francis M. Deng, "Frontiers of Sovereignty: A Framework of Protection, Assistance and Development for the Internally Displaced", Leiden Journal of International Law, Vol. 8, No. 2, 1995.

91 Monika Barthwal-Datta, Understanding Security Practices in South Asia: Securitization Theory and the Role of Non-State Actors, Routledge, London, 2012, p. 39.

92 See Robert Muggah, No Refuge: The Crisis of Refugee Militarization in Africa, Zed Books, London, 2013.

93 See Mary-Jane Fox, "Child Soldiers and International Law: Patchwork Gains and Conceptual Gains", Human Rights Review, Vol. 7, No. 1, 2005; Mary-Jane Fox, "Girl Soldiers: Human Security and Gendered Insecurity", Security Dialogue, Vol. 35, No. 4, 2004. 
civilian and military space is not clear". ${ }^{94}$ Although militarization does not automatically equate with securitization, Young Hoon Song suggests that the two are inherently interconnected for IDPs living in Kenya and Sudan. Another indicator of the securitization dynamics at work when it comes to the protection of all IDPs are the existential threats faced by humanitarian actors attempting to reach and help them. ${ }^{95}$ In many circumstances, they are not simply targets of attack. They are also kidnapped, held hostage and executed.

Against these backdrops, it is surprising that the flight of IDPs and the types of violence surrounding their protection has attracted so little attention in security and securitization studies. This missing category of concern is even more surprising if one looks at the numbers. For instance, several studies have reported that the number of IDPs forcibly displaced across the globe far exceeds the number of refugees and asylum-seekers. ${ }^{96}$ According to a 2017 report compiled by the Internal Displacement Monitoring Centre, "there are currently twice as many IDPs as refugees in the world". ${ }^{97}$ In an earlier report, UNHCR estimated that in 2015 there were 21.3 refugees, 40.8 million IDPs and 3.2 million asylumseekers. ${ }^{98}$ If these numbers are true, why are we not talking about an "IDP crisis" as a bigger security issue? Perhaps it is because IDPs have not crossed an internationally recognized State border. By not crossing any internationally recognized State border, IDPs fail to qualify for the same legal protections as refugees. In effect, this means that the linguistic distinction drawn between IDPs and refugees is premised predominantly on the fact that this kind of movement occurs within national borders. ${ }^{99}$ By extension, certain types of internal displacement will not concern the international community or infer any obligations onto it, since IDPs "really only need access to meaningful enforcement of generic internationally recognized human rights". ${ }^{100}$

Another reason why IDPs may be missing from the dominant security narratives is because there is no consensus on what this category means, who

94 Y. H. Song, above note 81, p. 127.

95 For further reading on this topic, see the thematic issues on "Violence Against Health Care" (Parts I and II), International Review of the Red Cross, Vol. 95, Nos 899-890, 2013; Y. H. Song, above note 82, pp. 124129; Larissa A. Fast, "Mind the Gap: Documenting and Explaining Violence Against Aid Workers", European Journal of International Relations, Vol. 16, No. 3, 2010; J. Vaughn, above note 88; Caroline Abu Sa'Da, “Attacks on Medical Missions: Overview of a Polymorphous Reality: The Case of Médecins Sans Frontières", International Review of the Red Cross, Vol. 95, No. 890, 2013.

96 Nils Geissler, "The International Protection of Internally Displaced Persons", International Journal of Refugee Law, Vol. 11, No. 3, 1999.

97 International Displacement Monitoring Centre, Global Report on Internal Displacement, Geneva, 2017, available at: www.internal-displacement.org/global-report/grid2017/.

98 UNHCR, Global Trends: Forced Displacement in 2015, Geneva, 2016, p. 2, available at: s3.amazonaws.com/ unhcrsharedmedia/2016/2016-06-20-global-trends/2016-06-14-Global-Trends-2015.pdf.

99 UNHCR, The Guiding Principles on Internal Displacement, Geneva, 1998, available at: www.unhcr.org/uk/ protection/idps/43celcff2/guiding-principles-internal-displacement.html. Also see Roberta Cohen, "The Guiding Principle of Internal Displacement: An Innovation in International Agenda Setting", Global Governance, Vol. 10, No. 4, 2004.

100 James C. Hathaway, "Forced Migration Studies: Could We Agree Just to 'Date'?", Journal of Refugee Studies, Vol. 20, No. 3, 2007, p. 359. 
should be included and when internal displacement ends. ${ }^{101}$ Depending on which definition is put into use, people who are internally displaced share certain family resemblances with migrants and refugees-indeed, they can be labelled as "internal refugees" or "economic migrants". ${ }^{102}$ Yet, many oppose stretching the definition of IDPs in these directions as it jettisons any specific focus given to this category of persons. Beyond the language games of migrant and refugees, however, a more complex fractioning of the IDP category is already occurring around the world. Documenting the mass flight of people from Iraq after 2003, for example, Géraldine Chatelard noted that "vulnerabilities span different categories of people: registered and non-registered IDPs or returnees, but also displaced and non-displaced persons". ${ }^{103}$ To capture and adapt to these complexities, it is necessary not to fall into the trap of simply "relabelling populations with new words". ${ }^{104}$ On the contrary, Peter Van der Auweraert has already identified that "the 'slicing up' of the displaced and returning families into different categories" can produce, rather than reduce, the kinds of obstacles facing IDPs. ${ }^{105}$ Cathrine Brun has also documented the "unintended consequences following ... the establishment of the IDP category". ${ }^{106}$

To say the least, then, the plight of the internally displaced deserves far more attention and linguistic nuance than it is currently afforded when we talk about people on the move in search of security. This point must hold even though IDPs never cross international borders, and even if they never cross into mainstream securitization studies. Finding connections between IDPs and security will not be difficult. As Marguerite Contat Hickel explains, "no action to provide effective and lasting protection can be contemplated unless there is a satisfactory security environment". ${ }^{107}$ The key challenge will be to create (de)securitized games in which IDPs are not simply spoken about but also spoken to, through gestures of kindness and love. ${ }^{108}$

101 Erin Mooney, "The Concept of Internal Displacement and the Case for Internally Displaced Persons as a Category of Concern”, Refugee Survey Quarterly, Vol. 24, No. 3, 2005.

$102 \mathrm{Ibid}$. Also see Roger Zetter, "More Labels, Fewer Refugees: Remaking the Refugee Label in an Era of Globalization", Journal of Refugee Studies, Vol. 20, No. 2, 2007; Cathrine Brun, "Local Citizens or Internally Displaced Persons? Dilemmas of Long Term Displacement in Sri Lanka", Journal of Refugee Studies, Vol. 16, No. 4, 2003.

103 Géraldine Chatelard, "Iraqi Refugees and IDPs: From Humanitarian Intervention to Durable Solutions", Middle East Institute-Fondation pour la Recherche Stratégique (MEI-FRS) Analysis Report, 9 June 2011, p. 16, available at: www.humanitarianlibrary.org/sites/default/files/2013/05/09_chatelard.pdf.

104 Georigia Cole, "Beyond Labelling: Rethinking the Role and Value of the Refugee 'Label' Through Semiotics", Journal of Refugee Studies, Online First View, DOI 10.1093/jrs/fex021, 2017, p. 3.

105 Peter Van der Auweraert, "Displacement and National Institutions: Reflections on the Iraqi Experience", MEI-FRS Analysis Report, 6 June 2011, p.8, available at: www.refugeecooperation.org/publications/iraq/ pdf/08_auweraert.pdf.

106 C. Brun, above note 102, p. 377.

107 Marguerite Contat Hickel, "Protection of Internally Displaced Persons Affected by Armed Conflict: Concept and Challenges", International Review of the Red Cross, Vol. 83, No. 834, 2001, pp. 705-706.

108 For a similar idea, see Paul Bouvier, "Humanitarian Care and Small Things in Dehumanised Places", International Review of the Red Cross, Vol. 94, No. 888, 2012. 


\section{Acceptance and evolving language games: The way forward?}

This article has focused on complex topics that surely warrant further discussion. Overall, it has questioned the soundness of numbers as a beneficial blueprint for protecting migrants, refugees or IDPs. It also cautioned against the proliferation of security narratives that resuscitate and naturalize storylines of "inherent" catastrophes and crises. It is important to bear in mind that security is unbound in the sense that it has no fixed meaning. However, this outlook does not legitimate the escalation of unbound securitized games. A general finding of this article is that once securitization occurs, it can be extremely difficult to unmake. By extension, desecuritization is not an automatic guarantee even if the general consensus is that "it ought to be sought". ${ }^{109}$

That said, this article is careful not to undermine the integrity and relevance of ongoing efforts to protect migrants, refugees and IDPs. It also does not want to nullify the prospects of change as we go forward. At this point, one may certainly ask what remains to be done. While second-generation scholars have already begun to explore the role of emotions and feelings in securitization processes, more energy must be put into understanding if, when and how these individuals feel threatened or protected or a mixture of both. Acceptance will be a vital tool to taking steps in this direction. To date, the concept of acceptance put into use in securitization studies has rotated around the ability of certain audiences to support the (de)securitizing moves enacted by securitizing actors and speakers. Extending an unconditional invitation to migrants and refugees whenever and wherever they arrive on our shores is a very different logic of acceptance. Acknowledging that too many people are still missing in our efforts to solve the ongoing "migrant" and "refugee" crises will also require a broader conceptualization of acceptance-including IDPs into our analysis is simply the tip of the iceberg. In the end, perhaps what it all comes down to is a hope that we can accept that we are all equals. Dr Martin Luther King Jr expressed this idea far more eloquently in his Nobel Peace Prize, when he said:

Sooner or later all the people of the world will have to discover a way to live together in peace .... If this is to be achieved, man must evolve for all human conflict a method which rejects revenge, aggression and retaliation. The foundation of such a method is love. ${ }^{110}$

Only time will tell if this kind of love is attainable in the name of (de)securitization. For some scholars, activists and policy-makers, the conceptual foundation that $\mathrm{Dr}$ King called for will be labelled as utopian and naive. For others, carving out broader understandings of acceptance and love will be out of sync with the "us" versus "them" identities that the securitization process constructs, and the 
extraordinary measures that are legitimated in the process. Presumably, others will contend that moves in these directions will generate conceptual confusion rather than any analytical rigor. Each reader must make their own decisions about which arguments hold weight for them. However, the brief assessment of the (de) securitized games at play when it comes to the protection of migrants, refugees and IDPs presented above illustrates that we must wrestle with broader themes of acceptance and love if we are to genuinely try to create alternative narratives in order to talk to migrants, refugees and IDPs long before we read about them in another journal article such as this one. This article also concludes that returning to these conversations with a richer conceptualization of acceptance and love in tow may help us to move the terms of reference away from extraordinary measures and towards long-term solutions. ${ }^{111}$

111 See Shin Chiba, "Hannah Arendt on Love and the Political: Love, Friendship and Citizenship", Review of Politics, Vol. 57, No. 3, 1995; Marita Eastmond, "Stories of Lived Experience: Narratives in Forced Migration Research", Journal of Refugee Studies, Vol. 20, No. 2, 2007. 